\title{
Social media and its adverse effect on academic performance of students
}

\author{
Sohail Khan ${ }^{a, 1, *}$, Abdulsatar Abduljabbar Sultan ${ }^{\mathrm{a}, 2}$, Salwa Alsamarai b,3 \\ ${ }^{a}$ Business Administration, Lebanese French University \\ ${ }^{\mathrm{b}}$ Information Management Systems Department, Isra University \\ ${ }^{1}$ sohailkhan@lfu.edu.krd*; ${ }^{2}$ abdulsatar1@lfu.edu.krd; ${ }^{3}$ salwa_alsmarai@yahoo.com \\ * corresponding author
}

\begin{tabular}{|c|c|}
\hline ARTICLE INFO & ABSTRACT \\
\hline $\begin{array}{l}\text { Article history } \\
\text { Received January 8, } 2019 \\
\text { Revised January 25, } 2019 \\
\text { Accepted February 14, } 2019 \\
\text { Keywords } \\
\text { Academic performance } \\
\text { Social media }\end{array}$ & $\begin{array}{l}\text { The researchers carry this project to know the negative effect of Social Media on } \\
\text { the students' academic performance. Survey method was used to collect the } \\
\text { primary data. Sample size was } 197 \text { respondents. The respondents are students of } \\
\text { Erbil City (Iraq). Data was analyzed using Correlation of Variables, ANOVA and } \\
\text { Regression with the help of SPSS software. The study revealed that Time Waste, } \\
\text { Cause of Distraction and Reduced Command over Language as the most } \\
\text { responsible factors for Social Media to affects the students academic performance. } \\
\text { However, the researcher found no significance in the variable of Reduction in Real } \\
\text { Human Contact. }\end{array}$ \\
\hline
\end{tabular}

This is an open access article under the CC-BY-SA license.

\section{Introduction}

In this era, communication is the most well-known term. Today, the communication united us paying little mind to geological limits. The Internet offers a wide assortment of specialized apparatuses. Billions of individuals make use of the Internet for searching, messaging, watching movies and songs, etc [1]. The use of the Internet is increasing day by day and students are not spared from it. As of late; utilization of online networking has turned out to be well known all around the globe because of an incredible improvement of innovation. Many students have a habit to $\log$ in to their Social Media account such as on Facebook, Twitter, etc. as a part of their everyday routine. Millions of students are logging in to these social networking sites, regularly and every day [2]. This is the reason why many students do not perform well in their exams and have been blaming Social Media for it. Therefore, this study is undertaken to know the negative effects of social media on the academic performance of students.

Numerous specialists have been researching the internet based life impacts on undergrads. In spite of the past work covers different effects in different territories, this investigation will concentrate on the academic performance effect of understudies in Erbil city of Iraq, because of the utilization of internet-based life. The research work is carried out with an intention to find out the impact of Social Media and to know its adverse effects on their academic performance of the students. It also tries to throw some light on the major factors which are responsible for the poor academic performance due to excessive usage of social media.

This research paper is organized as follows. Section 1 above presented the background and objective of this study. Section 2 describes the related studies for the relationship of social media usage and academic performance. It also includes the conceptual framework. Section 3 explains the methodology used throughout this paper. In Section 4, data analysis and presentation is explained thoroughly. Section 5, presents the conclusion and finally, section 6 presents the recommendation followed by future research scope. 
A large number of researchers have conducted research on Social Media and its influence on students' academic performance and found a negative impact on it. Khan along with Madan Mohan and Prabhu, brought up that Facebook users committed lesser time to their investigations in contrast with non-users did and in this way had lower GPAs [3], [4]. A large portion of the more youthful students utilizes social media mainly for mingling activities, instead of for studying purpose and thus gets distracted from the studies [5]. Furthermore, most of the relations on Social Media are not genuine and there is a reduction in real human contact. Jeong, noticed that internet dependency is all together and negatively related to the academic performance of students' just as passionate characteristics [6]. He further added that it is a waste of time. In addition, Seo supports Jeong's declaration when he opined that the negative impact of the web is just one extreme clients and not on all clients [7]. Malaney opined that because of social media, students' grades have suffered a lot as they were spending a lot of time on social media [8]. A Similar study conducted by Banquil et al, found clear evidence of a continuous drop in the academic performance because of the use of Social Network [9]. Some studies have even reported to negatively related to the use of Facebook and students' academic performance. Rouis et al., conducted research on Swedish students and revealed that extensive use of Social Media particularly Facebook has led to the poor performance of Swedish students and also there is a decrement in the command on language [10]. Another researches found a negative impact caused by social media on the student's performance [11], [12]. They said that the students majorly assess inappropriate contents and do not understand online privacy. They further added there is a risk of online harassment and cyber bullying. Kuppuswamy et.al. in their study said that social networking sites firstly attract the attention of the students on educational purpose and then slowly students indulge themselves on non-academics and inappropriate actions which majorly includes chatting [13]. Hence, it was concluded by them that social networking sites are the major cause of distraction and had badly affected the learning experiences and academic life of the student. According to Karpinski, social media means negative growth of students [14]. He said that Social media has more disadvantages than advantages in the academic performance of the students. He further added that more and people are using and students are no an exception to it. Hence, slowly they become addicted to it. Hurt et al., concluded that Social media provides too much simulation and therefore distract students from completing their Class work and assignments [15]. According to the different literature studied, Fig. 1 shows the theoretical research framework.

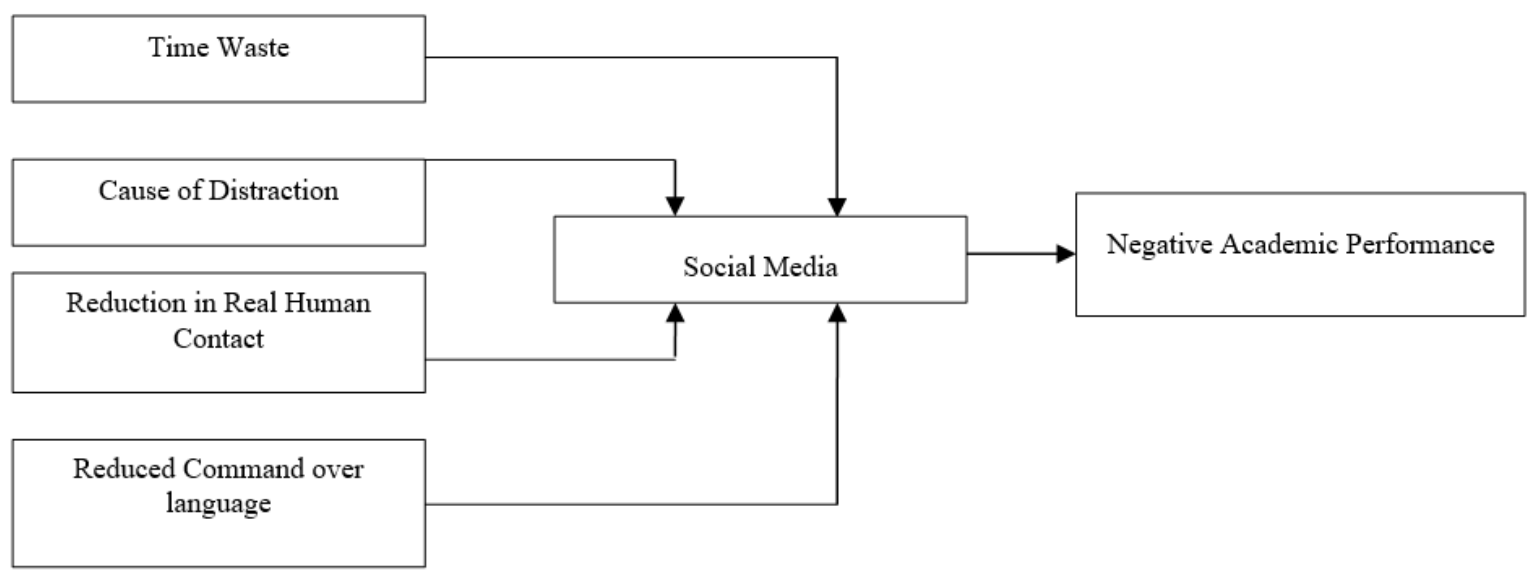

Fig. 1.Conceptual framework.

Nyland et al., conducted an online survey in US of 184 Internet users and found that individuals who invest more energy and time on Social Media were thought to be less mingled with their own communities [16]. In addition, a study with the title "Impact of Facebook on undergraduate academic performance", and reveled that social media has an advert effect on students' performance [17]. The outcome revealed that the more understudies use Facebook, the more it influences their scholastic execution. Another researchers investigate the outcome of Use of Social networking among college students with their academic performance and discovered a poor impact and influence when the media is abuse so that don't scholastically improve learning or its procedure [18]. 


\section{Method}

At first, a detailed survey of the literature is done on history, improvement, negative connect and connection between academic performance and the use of Social Media. The Descriptive research design was used to comprehend the issue and complete the research in a clear way. For this research, the target population was characterized as the students who structure the significant chunk of users of Social Media. The area of study is Lebanese French University, Erbil Iraq. After secondary information accumulation through information gathering over the web, primary research was helped out through a questionnaire. By using simple random sampling technique, two hundred (200) students were randomly selected from the total population. 197 questionnaires were retrieved from the study (giving a response rate of 98.5\%) making a total sample size of 197, after which descriptive statistics was used to carry out the research work. the data was collected between December 2018 January 2019. The Questionnaire used for collecting data consists of five questions each of the independent variables. The questionnaire was planned and designed in such a way that the respondents needed to rank utilizing a Likert scale to show their dimension of agreement or disagreement. The survey was very much organized and the reactions were recorded systematically from the respondents for data analysis.

\section{Result and Discussion}

Table 1 and 2 explains the demographic profile of Respondents. For this research work $58.4 \%$ male and $41.6 \%$ of female actively participated. Most of the respondents $(55.3 \%)$ are in the age range of 21 to 25 years. $20.3 \%$ of respondents were in the age range on 15 to 20 years. 36/197 are in the age group of 26 to 30 years. Only 12 respondents were in age 31 to 35 years. There were no respondents above 35 years of age. Majority of the students were from II and IV Year. Academic performance of most of the students $(48.2 \%$ ) was very good. It can be interpreted that almost $75 \%$ of the respondents are using social media for more than three years and only a few $(6.1 \%)$ have started using social media less than six months ago. More than 56\% of students access their Social Media Daily. $46.2 \%$ of students use Social Media for four to seven hours and $26.4 \%$ of students are online on Social Media for one to three hours daily.

Table.1 Statistics of Demographic Profile

\begin{tabular}{cccccccc}
\hline & Gender Age Year & $\begin{array}{c}\text { Academic } \\
\text { Performance }\end{array}$ & $\begin{array}{c}\text { How Long using } \\
\text { Social Media }\end{array}$ & $\begin{array}{c}\text { Often Access } \\
\text { Social Media }\end{array}$ & $\begin{array}{c}\text { Frequency of use of } \\
\text { Social Media }\end{array}$ \\
\hline $\mathrm{N}$ Valid & 197 & 197 & 197 & 197 & 197 & 197 & 197 \\
\hline Missing & 0 & 0 & 0 & 0 & 0 & 0 & 0 \\
\hline
\end{tabular}

Table.2 Demographics profile of the Respondents (\%)

\begin{tabular}{|c|c|c|c|}
\hline & & Frequency & Percent \% \\
\hline \multirow{2}{*}{ Gender } & Male & 115 & 58.4 \\
\hline & Female & 82 & 41.6 \\
\hline \multirow{5}{*}{ Age (in years) } & $15-20$ years & 40 & 20.3 \\
\hline & $21-25$ years & 109 & 55.3 \\
\hline & 26 - 30 years & 36 & 18.3 \\
\hline & 31 - 35 years & 12 & 6.1 \\
\hline & More than 35 years & 0 & 0 \\
\hline \multirow{4}{*}{ Year } & I Year & 27 & 13.7 \\
\hline & II Year & 71 & 36.0 \\
\hline & III Year & 29 & 14.7 \\
\hline & IV Year & 70 & 35.5 \\
\hline \multirow{4}{*}{ Academic Performance } & Excellent & 45 & 22.8 \\
\hline & Very Good & 50 & 48.2 \\
\hline & Good & 75 & 38.1 \\
\hline & Medium & 27 & 13.7 \\
\hline \multirow{4}{*}{ How Long have been using Social Media } & 1-6 Months & 12 & 6.1 \\
\hline & 6 Months -1 Year & 9 & 4.6 \\
\hline & $1-3$ Year & 29 & 14.7 \\
\hline & $3-5$ Year & 86 & 43.7 \\
\hline
\end{tabular}




\begin{tabular}{|c|c|c|c|}
\hline & & Frequency & Percent\% \\
\hline & More than 5 Year & 91 & 31.0 \\
\hline \multirow{4}{*}{ How Often Access Social Media } & Daily & 111 & 56.3 \\
\hline & Weekly & 25 & 12.7 \\
\hline & Fortnightly & 22 & 11.2 \\
\hline & Monthly & 39 & 19.8 \\
\hline \multirow{6}{*}{ Frequency of using Social Media (Per Day) } & Less than 1 Hour & 29 & 14.7 \\
\hline & $1-3$ Hour & 52 & 26.4 \\
\hline & $4-7$ Hour & 91 & 46.2 \\
\hline & $8-12$ Hour & 23 & 11.7 \\
\hline & More than 12 Hours & 2 & 1.0 \\
\hline & Total & 197 & 100 \\
\hline
\end{tabular}

On the Table 3 it is clear that Students mostly use Instagram as Social Media. Thus, for Social Media, Instagram ranks first in the utilization of it followed by Facebook and Snapchat. Messenger and Viver ranks 4th and 5th place respectively. However, it is also clear that no student use LINE as Social Media.

Table.3 Preference of Type of Social Media

\begin{tabular}{ccc}
\hline Type of Social Media & Sum & Rank \\
\hline Instagram & 99 & 1 \\
\hline Facebook & 71 & 2 \\
\hline Snapchat & 58 & 3 \\
\hline Messenger & 49 & 4 \\
\hline Viber & 45 & 5 \\
\hline YouTube & 32 & 6 \\
\hline Twitter & 18 & 7 \\
\hline WhatsApp & 15 & 8 \\
\hline Skype & 9 & 9 \\
\hline WeChat & 5 & 10 \\
\hline Flickr & 3 & 11 \\
\hline Myspace & 3 & 11 \\
\hline LINE & 0 & 12 \\
\hline Any Other & 0 & 12 \\
\hline
\end{tabular}

Table.4 Correlation of Variables

\begin{tabular}{|c|c|c|c|c|c|}
\hline & $\begin{array}{c}\text { Negative } \\
\text { Effects of } \\
\text { Social Media } \\
\end{array}$ & Time Waste & $\begin{array}{c}\text { Cause of } \\
\text { Distraction }\end{array}$ & $\begin{array}{c}\text { Reduction in } \\
\text { Real Human } \\
\text { contact }\end{array}$ & $\begin{array}{c}\text { Reduced } \\
\text { Command } \\
\text { over language }\end{array}$ \\
\hline $\begin{array}{c}\text { Negative Effects of Social } \\
\text { Media }\end{array}$ & 1 & & & & \\
\hline Time Waste & .680 & 1 & & & \\
\hline Cause of Distraction & .304 & .459 & 1 & & \\
\hline $\begin{array}{c}\text { Reduction in Real Human } \\
\text { contact }\end{array}$ & .480 & .332 & .359 & 1 & \\
\hline $\begin{array}{l}\text { Reduced Command over } \\
\text { language }\end{array}$ & .504 & .418 & .257 & .243 & 1 \\
\hline
\end{tabular}

Table 4 shows the correlation between the different variables. It is reflects that there exists a positive relationship between the variables. It reflects a positive and significant correlation between 
Time waste, Cause of Distraction, Reduction in Real Human Contact and Reduces Command over Language. Independent Variables with values .504, .418, .257 and .243 respectively are significant at 0.01 level.

Table 5 depicts the model summary, through which it can be said that R2 value $74.3 \%$, it is the percent of the variation of the Negative effect of Social Media (i.e., coefficient of determination) in the outcome variable that is explained by the set of predictor variables (Reduced Command over language, Reduction in Real Human contact, Cause of Distraction, Time Waste). The adjusted R square is .725. Durbin-Watson test statistic is used to detect the presence of Autocorrelation in the prediction errors. From the table above it is clear that Durbin-Watson statistic is substantially less than two, hence there is clear evidence of a positive serial correlation between the predictors.

Table.5 Model Summary

\begin{tabular}{|c|c|c|c|c|c|c|c|c|c|c|}
\hline \multirow[b]{2}{*}{ Model } & \multirow[b]{2}{*}{$\mathbf{R}$} & \multirow[b]{2}{*}{$\begin{array}{c}\mathbf{R} \\
\text { Square }\end{array}$} & \multirow[b]{2}{*}{$\begin{array}{l}\text { Adjusted } \\
\text { R Square }\end{array}$} & \multirow{2}{*}{$\begin{array}{c}\text { Std. Error } \\
\text { of the } \\
\text { Estimate }\end{array}$} & \multicolumn{5}{|c|}{ Change Statistics } & \multirow[b]{2}{*}{$\begin{array}{l}\text { Durbin- } \\
\text { Watson }\end{array}$} \\
\hline & & & & & $\begin{array}{c}\text { R Square } \\
\text { Change }\end{array}$ & F Change & df1 & df 2 & $\begin{array}{c}\text { Sig. F } \\
\text { Change }\end{array}$ & \\
\hline 1 & $.878 a$ & .743 & .725 & .59791 & .743 & 83.023 & 4 & 192 & .000 & 1.881 \\
\hline
\end{tabular}

a. Predictors: (Constant), Reduced Command over language, Reduction in Real Human contact, Cause of Distraction, Time Waste

b. Dependent Variable: Negative Effects of Social Media

Table 6 shows result Analysis of Regression of dependent variable (Negative Effects of Social Media) and Independent Variables (Reduced Command over language, Reduction in Real Human contact, Cause of Distraction, Time Waste). Calculated $\mathrm{F}$ - value shows that when the result was compared to F-Tabulated was significant: $F(4 / 192)=83.023, p<0.005$, which directly implies that the selected independent variables were a significant variable that affects the performance of the students negatively (Dependent Variable).

Table.6 ANOVAb

\begin{tabular}{lcccccc}
\hline & Model & Sum of Squares & df & Mean Square & F & Sig. \\
\hline & Regression & 11.473 & 4 & 2.868 & 83.023 & $.000 \mathrm{a}$ \\
\cline { 2 - 6 } 1 & Residual & 68.639 & 192 & .357 & & \\
\cline { 2 - 6 } & Total & 80.112 & 196 & & & \\
\hline
\end{tabular}
$\begin{aligned} & \text { a. Predictors: (Constant), Reduced Command over language, Reduction in Real Human contact, Cause of Distraction, Time } \\
& \text { Waste }\end{aligned}$
b. Dependent Variable: Negative Effects of Social Media

Table 7 shows the result of Regression, which confirms the result of ANOVA with time waste, Cause of Distraction and Reduced Command over Language being significant, $t(7.961)=2.342$, 2.340 , and 2.104 respectively, $\mathrm{p}<0.05$. However, it was found from the table above that Reduction in Real Human Contact is not significant. The beta coefficient of Reduction in Real Human Contact is 1.173 is not statistically significant, that indicates that this variable (Reduction in Real Human Contact) will not significantly predict the outcome.

Table.7 Coefficients of Regression ${ }^{\text {a }}$

\begin{tabular}{|c|c|c|c|c|c|c|}
\hline & \multirow[t]{2}{*}{ Model } & \multicolumn{2}{|c|}{ Unstandardized Coefficients } & \multirow{2}{*}{$\begin{array}{c}\begin{array}{c}\text { Standardized } \\
\text { Coefficients }\end{array} \\
\text { Beta }\end{array}$} & \multirow[t]{2}{*}{$\mathbf{t}$} & \multirow[t]{2}{*}{ Sig. } \\
\hline & & B & Std. Error & & & \\
\hline \multirow{5}{*}{1} & (Constant) & 2.083 & .262 & & 7.961 & .000 \\
\hline & Time Waste & .176 & .075 & .201 & 2.342 & .020 \\
\hline & Cause of Distraction & .186 & .080 & .194 & 2.340 & .020 \\
\hline & $\begin{array}{c}\text { Reduction in Real Human } \\
\text { contact }\end{array}$ & .088 & .075 & .102 & 1.172 & .243 \\
\hline & $\begin{array}{l}\text { Reduced Command over } \\
\text { language }\end{array}$ & .125 & .059 & .155 & 2.104 & .037 \\
\hline
\end{tabular}

\footnotetext{
a. Dependent Variable: Negative Effects of Social Media
} 


\section{Conclusion}

This research work was carried to investigate the adverse effects of Social Media on the academic performance of the students. For this, four Parameters which effects the performance of Students negative were used. These four parameters were Time waste, Cause of Distraction, Reduction in Real Human Contact and Reduced Command over Language. Of these four mentioned variables Time Waste, Cause of Distraction and Reduced Command over Language being a significant coefficient and the only Reduction in Real Human Contact was not significant. It can be concluded that Social Media is adversely affecting the performance of the students as it majorly kills time. Thus keeping away the students from Studies. Secondly, it is the cause of distraction. And finally, it reduces the command over the language. Nevertheless, unfortunately, Instead of using social media for educational purpose, the students are significantly led by distraction, thus making them more use of various social media and very less time on studies.

As web-based life has turned into a vital part of the students' lives it will not be right to recommend them not to utilize it. Everybody is building up a nearby association with internet-based life and there is no possibility in preventing students from utilizing it. In this way, what is increasingly imperative is to control them on the most proficient method to use in a valuable manner. Secondly, students themselves must understand and should be educated of all the potential damage from inordinate utilization of social media, and responsibly approach the learning procedure and academic performance.

All research work has some scope for further research. This research work is also not free from that scope. For this research, researchers have used four Independent Variables. Another researcher can use more variables to extend the research also the data collected was close to 200. By increasing the sample size, the results are expected to vary.

\section{References}

[1] A. A. Sultan, S. M. Noor, and N. Nasirun, "Technological factors and e-commerce adoption among small medium enterprises in Kurdistan, Iraq," Int. J. Eng. Technol., vol. 7, no. 3.5, pp. 98-101, 2018.

[2] A. A. Sultan, M. G. Hassan, and S. M. Noor, "Proposing Conceptual Model in Assessing E-Commerce Adoption in Iraq and Malaysia," ASEAN Entrep. J., vol. 2, no. 1, pp. 1-10, 2016.

[3] U. Khan, "Facebook students underachieve in exams," Education News, 2009. [Online]. Available: https://www.telegraph.co.uk/education/educationnews/5145243/Facebook-students-underachieve-inexams.html. [Accessed: 14-Mar-2019].

[4] G. M. Mohan and M. Prabhu, "A Study on Students Perception about Facebook," Int. J. Contemp. Commer., vol. 1, no. 2, pp. 64-77, 2013.

[5] N. Oye, A. M. Helou, and Z. Z. A. Rahim, "Students' Perceptions on Social Networking Sites Influence on Academic Performance," Int. J. Soc. Netw. Virtual Communities, vol. 1, no. 1, pp. 7-15, 2012.

[6] T. G. Jeong, "The effect of internet addiction and self-control on achievement of elementary school children," Korean J. yeolin Educ., vol. 5, no. 3, pp. 143-163, 2005.

[7] W. S. Seo, "Internet usage and life satisfaction of youths," Inf. Policy, vol. 11, no. 2, pp. 17-27, 2004.

[8] G. D. Malaney, "Student use of the internet," J. Educ. Technol. Syst., vol. 33, no. 1, pp. 53-66, 2004.

[9] K. Banquil et al., "Social networking sites affect one's academic performance adversely," UST Coll. Nurs., pp. 1-42, 2009.

[10] S. Rouis, M. Limayem, and E. Salehi-Sangari, "Impact of facebook usage on students' academic achievement: role of self-regulation and trust," Electron. J. Res. Educ. Psychol., vol. 9, no. 3, pp. 961994, 2011.

[11]G. S. O'Keeffe and K. Clarke-Pearson, "The impact of social media on children, adolescents, and families," Pediatrics, vol. 127, no. 4, pp. 800-804, 2011.

[12]M. Prabhu and G. Madan Mohan, "A study on stress among university students in india," Int J Bus. Admin Res Rev, vol. 1, no. 5, pp. 21-33, 2014. 
[13] S. Kuppuswamy and P. S. Narayan, "The impact of social networking websites on the education of youth,” Int. J. virtual communities Soc. Netw., vol. 2, no. 1, pp. 67-79, 2010.

[14]A. C. Karpinski and A. Duberstein, "A description of Facebook use and academic performance among undergraduate and graduate students," in Annual Meeting of the American Educational Research Association, 2009, pp. 5-10.

[15]N. E. Hurt et al., "The" Facebook" Effect: College Students' Perceptions of Online Discussions in the Age of Social Networking," Int. J. Scholarsh. Teach. Learn., vol. 6, no. 2, p. n2, 2012.

[16] R. Nyland, R. Marvez, and J. Beck, "MySpace: Social networking or social isolation," in AEJMC Midwinter Conference, 2007, pp. 23-24.

[17]A. L. Moon, "The impact of Facebook on undergraduate academic performance: Implications for educational leaders," Central Michigan University, 2011.

[18]M. J. Stollak, A. Vandenberg, A. Burklund, and S. Weiss, "Getting social: The impact of social networking usage on grades among college students," Proc. from ASBBS Annu. Conf., vol. 18, no. 1, pp. 859-865, 2011. 